This is an electronic reprint of the original article. This reprint may differ from the original in pagination and typographic detail.

Author(s): Pehkonen, Jaakko; Sala, Hector; Salvador, Pablo

Title: $\quad$ The Nordic expericence revisited: labour market booms and slumps since the 1990s in Finland and Sweden

Year: $\quad 2011$

Version:

Please cite the original version:

Pehkonen, J., Sala, H., \& Salvador, P. (2011). The Nordic expericence revisited: labour market booms and slumps since the 1990s in Finland and Sweden. Journal of Economic Studies, 38(1), 52-65. https://doi.org/10.1108/01443581111096141

All material supplied via JYX is protected by copyright and other intellectual property rights, and duplication or sale of all or part of any of the repository collections is not permitted, except that material may be duplicated by you for your research use or educational purposes in electronic or print form. You must obtain permission for any other use. Electronic or print copies may not be offered, whether for sale or otherwise to anyone who is not an authorised user. 


\title{
The Nordic experience revisited: labour market booms and slumps since the 1990s in Finland and Sweden
}

\begin{abstract}
Purpose - This paper provides an account of the unemployment performance of two Nordic countries during their recent labour market booms and slumps.

Design/methodology/approach - Based on the empirical models of Karanassou, Sala and Salvador (2008), we conduct dynamic simulation exercises and explore the determinants of unemployment.

Findings - Our analysis yields two main findings. First, the capital stock was the most important determinant of the unemployment trajectory in both countries. This result appears in all periods considered: in the slump of the early nineties and the boom of the late nineties, as well as in the stabilisation period of the early 2000s. Second, the role of the external sector on the unemployment trajectory was significant in Finland, its quantitative impact being one third of that of capital stock in the first and third periods, and half in the second period.

Originality/value - Our results illustrate the importance of non-standard labour market variables in examining unemployment trajectories. The findings call for a wider than usual perspective in trying to solve the unemployment problem.

Keywords - Unemployment, Labour Market Dynamics, Capital Stock, Nordic countries Paper type - Research paper

JEL Classification Numbers: E22, E24, J21.

\section{Introduction}

This paper analyses the unemployment trajectory in two Nordic countries, Finland and Sweden, since the 1990s. The analysis of the labour market of these countries is tempting, since both countries came out of the oil crises of the 1970s with hardly any damage, while the 1990s crisis hit them extremely severely. Unemployment in Finland rose from 3 to 18 per cent over the period 1991-1994, while that in Sweden rose from 2 to 9 per cent over the same period. The unemployment trajectories of these countries are of a special appeal since they were similar in the timing of the rise in unemployment from the trough in 1990 to the peak in 1994, but they differed in the size of the rise and in the unemployment evolution after the peak. In particular, Finnish unemployment steadily decreased after the peak in 1994, while Swedish unemployment remained constant at around 8 per cent between 1994
\end{abstract}


and 1997.

The purpose of this study is straightforward: to provide an account of the driving forces shaping unemployment in Finland and Sweden over the last fifteen years. We do this by utilising the empirical models of Karanassou, Sala and Salvador (2008) to conduct new simulation exercises and further explore the determinants of unemployment. The analysis differs from theirs in two respects. First, we examine the unemployment effects of the whole set of explanatory variables, not only of changes in capital stock, on the Finnish and Swedish unemployment trajectories. Second, we evaluate the impact of these exogenous variables in three different periods since 1990, instead of just focusing on the episodes of high unemployment.

The rest of the paper is structured as follows. Section 2 presents empirical labour market models for Finland and Sweden, and explains how the simulation exercise is performed. Section 3 provides the accounts of unemployment performance. The analysis suggests that capital stock had an important role in the unemployment trajectory of both countries, especially during the Finnish unemployment upturn in the 1990s. Fiscal policy also played an important role in Finland during the first part of the 1990s, but its role was modest in the second part of this decade, as well as throughout the 1990s in Sweden. The external sector significantly influenced the Finnish unemployment trajectory. Finally, variations in participation rates had an impact on Finnish and Swedish labour markets during the 1990s. Section 4 concludes.

\section{Analytical framework}

The unemployment experience of the Nordic countries has recently been investigated by Karanassou, Sala and Salvador (2008), who measured the extent to which capital stock has shaped the unemployment movements in Denmark, Finland and Sweden in periods of high unemployment. By using kernel density analysis of the capital stock growth rate, the authors identify the temporary and permanent downturns in capital accumulation and show that the investment downturns drive the intensity and longevity of the unemployment upturns.

This study utilises the labour market models estimated in Karanassou, Sala and Salvador (2008, pp. 989-991) to extend their analysis and address the two objectives of this paper. Appendix 1 presents the variable definitions and Tables 1 and 2 reproduce, for Finland and Sweden respectively, the estimated equations for labour demand, wages and labour supply. Before we turn to our dynamic simulation exercise, we outline the main features of the estimated labour market equations.

\subsection{The Finnish and Swedish labour market models}

The Finnish labour market model (Table 1) implies that Finnish employment depends positively on capital stock and foreign demand, while real wages and real interest rates exert a negative influence. The latter two variables are also significant in Kiander and Pehkonen (1999), Honkapohja and Koskela (1999) and Fregert and Pehkonen (2009). The wage setting equation shows that unemployment negatively influences wages, whereas capital deepening, oil prices and the fiscal wedge exert a positive influence. Capital deepening is one of the most important determinants of Finnish wages in the studies of 
Kiander and Pehkonen (1999), Holden and Nymoen (2002) and Nymoen and R $\phi$ dseth (2003). Kiander and Pehkonen (1999) also find the influence of oil prices and the fiscal wedge to be significant. The labour supply is negatively driven by the unemployment rate through the discouraged workers effect, and positively by real wages and the participation rate.

Table 1: Finnish model, 1976-2005

\begin{tabular}{|c|c|c|c|c|c|c|}
\hline \multicolumn{3}{|c|}{$\begin{array}{l}\text { Dependent variable: } n_{t} \\
l_{t}\end{array}$} & \multicolumn{2}{|c|}{ Dependent variable: $w_{t}$} & \multicolumn{2}{|c|}{ Dependent variable: } \\
\hline$\overline{\text { cons }}$ & $\begin{array}{ll}t & 2.95 \quad[\end{array}$ & {$[0.004]$} & const & $1.52[0.037]$ & const & $3.76[0.000]$ \\
\hline$n_{t-1}$ & $0.64[0.000]$ & $w_{t-1}$ & 0.80 & {$[0.000]$} & $l_{t-1}$ & $0.70[0.000]$ \\
\hline$\Delta n_{t-1}$ & $0.19[0.046]$ & $u_{t}$ & -0.59 & {$[0.000]$} & $\Delta l_{t-1}$ & $1.33[0.000]$ \\
\hline$w_{t}$ & $0.71[0.000]$ & $k_{t}^{n}$ & 0.22 & [0.039] & $\Delta l_{t-2}$ & $0.03 \quad[0.053]$ \\
\hline$w_{t-1}$ & $-0.95[0.000]$ & $\tau_{t}^{w}$ & 0.27 & [0.008] & $\Delta u_{t}$ & $-0.08 \quad[0.000]$ \\
\hline$k_{t}$ & $0.28[0.001]$ & $o_{t}$ & 0.02 & {$[0.003]$} & $\Delta u_{t-1}$ & $-0.01 \quad[0.444]$ \\
\hline$\Delta k_{t}$ & $1.87[0.001]$ & & & & $w_{t}$ & $0.05[0.000]$ \\
\hline$r_{t}$ & $-0.34[0.009]$ & & & & $\Delta w_{t}$ & $-0.03 \quad[0.027]$ \\
\hline \multirow[t]{3}{*}{$f d_{t}$} & $0.34[0.007]$ & & & & $z_{t}$ & $0.42[0.000]$ \\
\hline & & & & & $\Delta z_{t}$ & $0.85[0.000]$ \\
\hline & & & & & $\Delta z_{t-1}$ & $-1.86[0.000]$ \\
\hline s.e. & 0.011 & & & 0.012 & & 0.001 \\
\hline
\end{tabular}

P-values in square brackets; $\Delta$ is the difference operator; s.e. is the standard error of the regression.

Source: extracted from Tables 2-4 in Karanassou, Sala and Salvador (2008).

Sweden's employment is positively dependent on capital stock and negatively on real wages and indirect taxes (Table 2). Wages, in turn, depend on unemployment and capital deepening, both entering with the expected negative and positive sign, respectively. The latter variable is significant in Hjelm (2006), Holden and Nymoen (2002) and Nymoen and $\mathrm{R} \phi$ dseth (2003). Fiscal policy is an important factor in wage determination, with both direct and indirect taxes exerting a substantial influence. This is in line with Forslund (1995) as well as Fregert and Pehkonen (2009). The labour supply is negatively driven by the unemployment rate, and positively by real wages and the participation rate. 
Table 2: Swedish model, 1966-2005

\begin{tabular}{|c|c|c|c|c|c|c|c|}
\hline \multicolumn{2}{|c|}{$\begin{array}{l}\text { Dependent variable: } n_{t} \\
l_{t}\end{array}$} & \multicolumn{3}{|c|}{ Dependent variable: $w_{t}$} & \multicolumn{3}{|c|}{ Dependent variable: } \\
\hline const & $2.88[0.046]$ & const & 3.24 & {$[0.000]$} & const & 4.55 & {$[0.000]$} \\
\hline$n_{t-1}$ & $0.66[0.000]$ & $w_{t-1}$ & 0.62 & {$[0.000]$} & $l_{t-1}$ & 0.64 & [0.000] \\
\hline$n_{t-1}^{d 1}$ & $-0.001[0.140]$ & $\Delta w_{t-1}$ & 0.21 & [0.046] & $\Delta l_{t-2}$ & -0.33 & [0.000] \\
\hline$n_{t-1}^{d 2}$ & $-0.003[0.005]$ & $u_{t}$ & -0.67 & {$[0.004]$} & $u_{t}$ & -0.32 & {$[0.000]$} \\
\hline$w_{t}$ & $-0.78[0.000]$ & $k_{t}^{n}$ & 0.31 & {$[0.000]$} & $w_{t}$ & 0.08 & {$[0.000]$} \\
\hline$w_{t-1}$ & $0.67[0.000]$ & $\tau_{t}^{d}$ & 0.63 & [0.004] & $z_{t}$ & 0.32 & [0.000] \\
\hline$k_{t}$ & $0.22[0.002]$ & $\tau_{t-1}^{d}$ & -0.46 & {$[0.056]$} & & & \\
\hline$\Delta k_{t}$ & $2.56[0.000]$ & $\tau_{t}^{i}$ & -0.78 & [0.003] & & & \\
\hline$\tau_{t}^{i}$ & $-1.08[0.004]$ & & & & & & \\
\hline s.e. & 0.016 & & & 0.016 & & & 0.005 \\
\hline
\end{tabular}

P-values in square brackets; $\Delta$ is the difference operator; s.e. is the standard error of the regression. The multiplicative dummies in the labour demand, $n_{t-1}^{d 1}$ and $n_{t-1}^{d 2}$, capture a decrease in employment persistence over 1991-2005. Source: extracted from Tables 2-4 in Karanassou, Sala and Salvador (2008).

\subsection{Dynamic contributions of the exogenous variables}

We use these estimated systems to perform a dynamic accounting exercise and examine how much of the unemployment variation in Finland and Sweden is attributable to the explanatory variables. The empirical results of Tables 1 and 2 imply that in the case of Finland we can evaluate the impact of capital stock, the real interest rate, the fiscal wedge, the participation rate, foreign demand and oil prices. For Sweden, the influence of capital stock, indirect and direct tax rates, and the participation rate in shaping the unemployment trajectory will be evaluated.

Three periods that coincide with turning points in unemployment are considered. The first turning points are, respectively, 1990 in Finland and 1989 in Sweden, when Finnish and Swedish unemployment started a rising trend that lasted until 1993/1994. Unemployment rates started to decline in the mid-1990s, which marks the second period from 1994 to 2001 in Finland and from 1993 to 2001 in Sweden. The third period, from 2001-2005, coincides with a rising trajectory of unemployment in Sweden and a stabilisation of Finnish unemployment. We label these three periods as the early nineties slump, the roaring nineties, and the end of the wild ride.

To provide a quantitative account of how each variable affects the unemployment rate, we follow the methodology presented by Karanassou and Sala, which consists of the estimation of their dynamic contribution to the unemployment trajectory. ${ }^{1}$ The procedure is the following. First, we set all the explanatory variables simultaneously at a certain date to

\footnotetext{
${ }^{1}$ See Karanassou and Sala (2009a and 2009b) and the references provided therein. More specifically, refer to the analytical definition and discussion provided in the first of these papers on what a dynamic contribution is.
} 
create a new (virtual) path of unemployment over a specific period. We then contrast the actual and simulated unemployment series, the difference between them being the dynamic contribution of all the exogenous variables. Next, we assess the impact of the exogenous variables individually by fixing one exogenous variable at a time and create a virtual path of unemployment for that particular variable.

This methodology can be illustrated by using the Finnish model. Actual unemployment rates in Finland in 1990 and 1994 were, respectively, 3.2 and 18.2 per cent. The difference of 15 percentage points is the actual unemployment upturn that occurred in the early 1990s, which in Table 3 is denoted as $\mathrm{A} u$. We first fix all the exogenous variables at their 1990 values and simulate the model. This yields a simulated unemployment rate reaching 10.9 per cent in 1994 - instead of the actual 18.2 per cent. We interpret this result as follows: had the labour market conditions in Finland remained as in 1990, its unemployment rate would have been 7.3 percentage points lower in 1994 than it actually was (which is denoted by $\mathrm{A} u^{\text {sim }}$ in Table 3). We then fix the exogenous variables separately, simulate the resulting model, and compute the simulated unemployment change attributable to each particular variable. We conduct this analysis for the two economies in all three periods.

\section{The Nordic experience revisited}

\subsection{The early nineties slump, 1989/90-1993/4}

In the early 1990s, Finland and Sweden experienced one of their most severe crises. The Finnish unemployment rate went up 15 percentage points between 1990 and 1994 and the Swedish unemployment rate rose by 7.1 percentage points between 1989 and 1993 (see Table 3 and Figure 1). Had the good macroeconomic conditions remained at the levels of the late 1980s, the unemployment rate would have been 7.3 percentage points lower in Finland and 8.2 percentage points lower in Sweden.

The simulations results indicate that capital stock played an important role in both countries, the impact being particularly strong in Finland. Monetary policy, proxied by interest rates, had a modest impact on unemployment in Finland. The external sector (foreign demand and oil prices) was a positive counterpart to the negative influence exerted by capital accumulation. Had foreign demand and oil prices remained at their 1990 levels, the Finnish unemployment rate would have been 5.3 percentage points higher in 1994. Fiscal policy played a minor role in Sweden but a major one in Finland: had the fiscal wedge remained at its original level, Finnish unemployment would have been 3.3 percentage points higher in 1994. Similarly, changes in the participation rate had a significant impact in Finland (3.5) but only a minor one in Sweden (0.8).

Table 3: Simulated unemployment changes attributable to each variable during the early nineties slump

\begin{tabular}{llllllll}
\hline & $\Delta u$ & $\Delta u^{\operatorname{sim}}$ & $\Delta u^{k}$ & $\Delta u^{r}$ & $\mathrm{~A} u^{f d+o}$ & $\Delta u^{f p}$ & $\mathrm{~A} u^{z}$ \\
\hline Finland, 1990-1994 & 15.0 & -7.3 & -19.9 & 0.5 & 5.3 & 3.3 & 3.5 \\
Sweden, 1989-1993 & 7.1 & -8.2 & -8.4 & - & - & -0.6 & 0.8 \\
\hline
\end{tabular}

Note: $\Delta u=$ actual unemployment change; $\Delta u^{\text {sim }}=$ simulated unemployment change with all the exogenous variables fixed; $f p=$ fiscal policy refers to the fiscal wedge in Finland, and to direct and indirect taxes in Sweden. 
Figure 1. Simulated unemployment trajectories during the early nineties slump
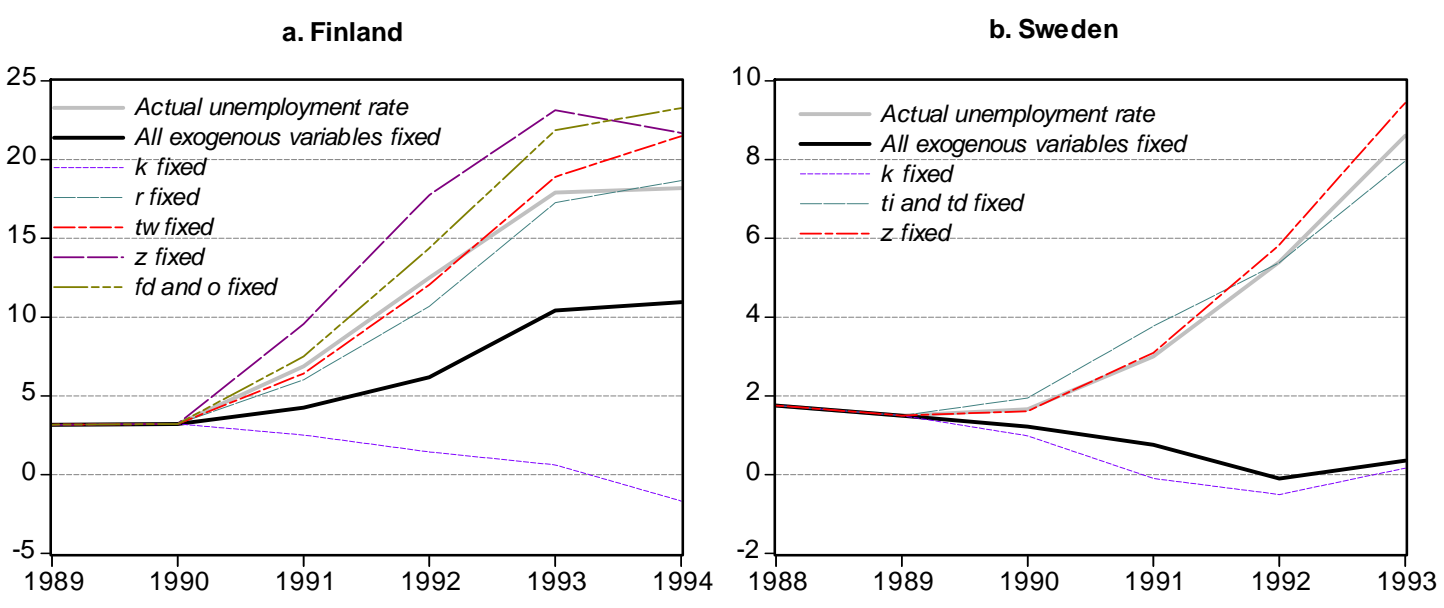

\subsection{The roaring nineties, 1993/4-2001}

After the deep recession of the early 1990s, both countries experienced a strong recovery that prompted a steady decline in unemployment. Finnish unemployment fell by 8.6 percentage points from 18.2 per cent in 1994 to 9.6 per cent in 2001. Swedish unemployment went down by 4.5 percentage points, from 8.6 per cent in 1993 to 4.1 per cent in 2001 (see Table 4 and Figure 2). The quasi-halving of these rates is the central expression of the roaring nineties in the Nordic countries.

Our simulations indicate that unemployment in Finland would have been 11.2 percentage points higher in 2001 had the macroeconomic conditions remained at the 1994 situation. Under the same assumptions, the analysis for Sweden reveals a simulated unemployment rate 10.2 percentage points higher than the value actually achieved in 2001 .

The main feature in both countries is the positive influence exerted by capital stock. Had this variable remained at its original value, unemployment in 2001 would have remained high in Finland (at 16.4 per cent), and would have increased in Sweden (to 13.5 per cent). Interest rates in Finland fell by several percentage points in the second half of the 1990s. This prevented Finnish unemployment from going up by 2.4 percentage points in this period. The sharp fall in Finnish unemployment was also an outcome of the continued improvement of the external sector that started in 1990. Had foreign demand and oil prices remained at their 1994 levels, the Finnish unemployment rate would have been 3.8 percentage points higher in 2001.

Fiscal policy also influenced the labour market performance. Had the fiscal wedge remained unchanged, unemployment would have been 1.2 percentage points higher in 2001 in Finland. In Sweden, changes in direct and indirect taxes had a modest positive impact on Sweden's unemployment. Finally, changes in participation rates in response to economic activity were slow and modest in Sweden, where the participation rates started to increase again at the end of the 1990s. In Finland, they started to move up as early as in 1994 and had a significant impact. Without their rise of 3 percentage points, unemployment would have been 3.0 percentage points lower in 2001. This was a substantial counterpart to the 
positive influence exerted by the rapid growth in capital stock, the lower interest rates and strengthened international trade.

Table 4: Simulated unemployment changes attributable to each variable during the roaring nineties

\begin{tabular}{llllllll}
\hline & $\Delta u$ & $\Delta u^{\operatorname{sim}}$ & $\mathrm{A} u^{k}$ & $\mathrm{~A} u^{r}$ & $\mathrm{~A}_{u}^{f d+o}$ & $\Delta u^{f p}$ & $\mathrm{Au}^{z}$ \\
\hline Finland, 1994-2001 & -8.6 & 11.2 & 6.8 & 2.4 & 3.8 & 1.2 & -3.0 \\
Sweden, 1993-2001 & -4.5 & 10.2 & 9.4 & - & - & 0.6 & 0.3 \\
\hline
\end{tabular}

Note: $\Delta u=$ actual unemployment change; $\Delta u^{\operatorname{sim}}=$ simulated unemployment change with all the exogenous variables fixed; $f p=$ fiscal policy refers to the fiscal wedge in Finland, and to direct and indirect taxes in Sweden.

Figure 2. Simulated unemployment trajectories during the roaring nineties
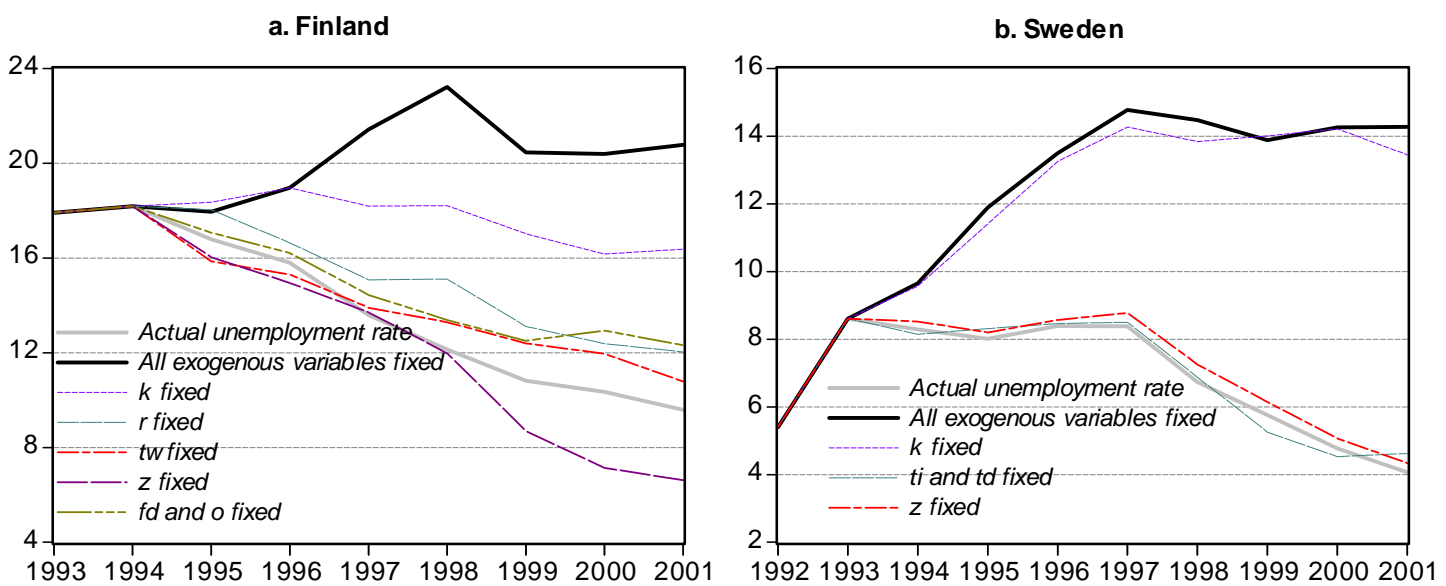

\subsection{The end of the wild ride, 2001-2005}

The strong expansionary period ended in 2001. Economic and capital stock growth subsequently decelerated and unemployment stopped its falling path: it increased in Sweden and gradually stabilised in Finland. In 2005 these rates were, respectively, 6 and 9 per cent. According to our analysis, the end of the wild ride would have not occurred in Finland and Sweden had the conditions of 2001 remained. Both countries would have had room for further improvements. Finnish unemployment would have gone down by a further 4.8 percentage points, instead of the actual 0.6 points decrease, gaining a rate of 4.2 per cent in 2005, a similar level to that before the early 1990s slump. In Sweden, the decline would have been 3.2 percentage points, instead of the observed 1.7 percentage point increase. This would have driven the unemployment rate to its full employment level of the early 1990s slump (see Table 5 and Figure 3).

Our results indicate that most of these changes have been driven by the effects of capital accumulation. Had capital stock remained unchanged in its 2001 situation, Finnish unemployment would have placed at 3.6 per cent in 2005, 5.4 percentage points below the actual figure of 9 per cent. In Sweden, the fall would have been 2.9 percentage points. 
Fiscal policy and variations in participation rates had little effect on these labour markets in this period. The fiscal wedge in Finland and direct and indirect taxes in Sweden did not notably change. Had these variables remained at their original values, unemployment would have changed by less than half a percentage point in both countries. The monetary policy in Finland had hardly any impact in the early 2000s. Finally, the external sector positively influenced Finnish unemployment. Had foreign demand and oil prices remained unchanged, Finnish unemployment would have increased by 1.4 percentage points in 2005 .

Table 5: Simulated unemployment changes attributable to each variable during the end of the wild ride

\begin{tabular}{lccccccc}
\hline & $\Delta u$ & $\Delta u^{\text {sim }}$ & $\mathrm{A} u^{k}$ & $\mathrm{~A} u^{r}$ & $\mathrm{~A} u^{f d+o}$ & $\Delta u^{f p}$ & $\mathrm{~A} u^{z}$ \\
\hline Finland, 2001-2005 & -0.6 & -4.8 & -5.4 & -0.3 & 1.4 & -0.3 & -0.3 \\
Sweden, 2001-2005 & 1.7 & -3.2 & -2.9 & - & - & -0.5 & 0.1 \\
\hline
\end{tabular}

Note: $\Delta u=$ actual unemployment change; $\Delta u^{\operatorname{sim}}=$ simulated unemployment change with all the exogenous variables fixed; $f p=$ fiscal policy refers to the fiscal wedge in Finland, and to direct and indirect taxes in Sweden.

Figure 3. Simulated unemployment trajectories during the end of the wild ride
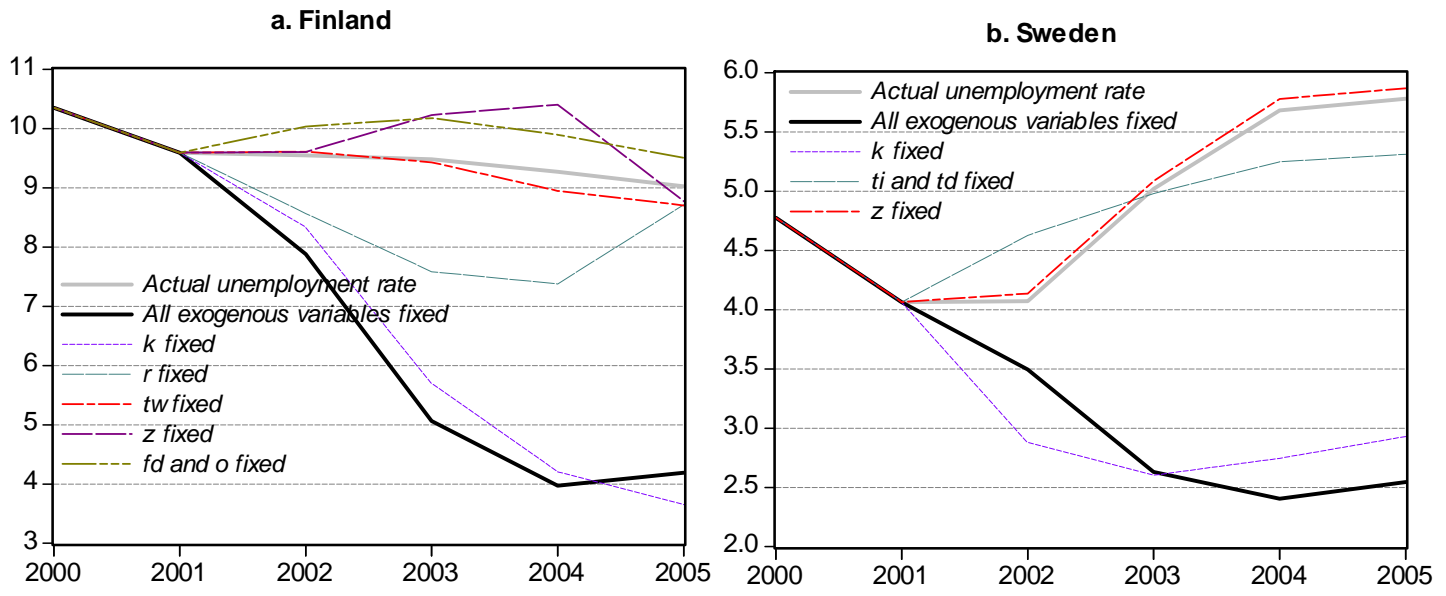

\section{Conclusions}

In this paper we conducted dynamic simulations to provide an account of the labour market performance of two Nordic countries since the 1990s. In particular, we examined how much of the Finish and Swedish unemployment variation was attributable to different explanatory variables in three periods of interest. Our results illustrate the importance of non-standard labour market variables in examining unemployment trajectories. According to our simulation results, capital stock was the most important determinant of the unemployment trajectory. In the early 1990s, it contributed significantly to the 15 and 7.1 percentage points increase in Finnish and Swedish unemployment rates, respectively. It avoided a rise in unemployment in Finland and Sweden of 6.8 and 9.4 percentage points, respectively, in the late 1990s. In the early 2000s, it impeded a 5.4 and 2.9 percentage 
points fall in the Finnish and Swedish unemployment rates, respectively. The other main determinant of Finland's unemployment was the external sector, its quantitative impact varying from one third to a half of that of capital stock, depending on the period analysed. Fiscal policy and participation rates also had a significant role, particularly in Finland. Their impact, approximately 20 per cent of that of capital stock, was strongest in the early 1990s.

These results add to recent empirical evidence on the crucial role exerted by capital stock on the labour market performance in EMU countries (Arestis, Baddeley and Sawyer, 2007), the Nordic economies including Denmark (Karanassou, Sala and Salvador, 2008), and Spain (Raurich, Sala and Sorolla, 2009; and Karanassou and Sala, 2009a). This supports Stockhammer's (2004) claim that the NAIRU model, and therefore the wage-push factors, provide only a partial explanation of the unemployment problem, and that capital accumulation is a crucial driving force both in European countries and the US.

\section{References}

Arestis, P., M. Baddeley, and M. Sawyer (2007), "The relationship between capital stock, unemployment and wages in nine EMU countries", Bulletin of Economic Research, 59 (2), pp. 125-148.

Forslund, A. (1995), "Unemployment - is Sweden still different?", Swedish Economic Policy Review, 2, 25-58.

Fregert, K. and J. Pehkonen (2009), "The crises of the 1990s and unemployment in Finland and Sweden", in L. Jonung, J. Kiander and P. Vartia (eds.) The Crises of the 1990s in Finland and Sweden, Edward Elgar, forthcoming. Also available as Lund Working Paper No 14, 2008.

Hjelm, G. (2006), "Simultaneous determination of NAIRU, output gaps and structural budget balances: Swedish evidence", in Mazzi, G.L. and Savio, G. (eds.), Growth and Cycle in the Eurozone, Palgrave, McMillan.

Holden, S. and R. Nymoen (2002), "Measuring structural unemployment: NAWRU estimates in the Nordic countries", The Scandinavian Journal of Economics, 104 (1), pp. 87-104.

Honkapohja, S. and E. Koskela (1999), "Finland's depression: a tale of bad luck and bad policies", Economic Policy, 14 (29), 400-436.

Karanassou, M. and H. Sala (2009a), "The rise and fall of Spanish unemployment: A chain reaction theory perspective", International Papers in Political Economy, forthcoming. (Also available as IZA Discussion Paper No. 3712, 2008).

Karanassou, M. and H. Sala (2009b), "Labour market dynamics in Australia: What drives unemployment?", IZA Discussion Paper No. 3924, Bonn.

Karanassou, M., H. Sala and P.F. Salvador (2008), "Capital accumulation and unemployment: new insights on the Nordic experience," Cambridge Journal of Economics, 32 (6), pp. 977-1001.

Kiander, J. and J. Pehkonen (1999), "Finnish unemployment: observations and conjectures", Finnish Economic Papers, 9, 72-88.

Nymoen, R. and A. R ${ }^{\phi}$ dseth (2003), "Explaining unemployment: some lessons from Nordic wage formation", Labour Economics, 10, pp. 1-29. 
Raurich, X., H. Sala, and V. Sorolla (2009), " Labour market effects of public capital stock: evidence for the Spanish private sector", International Review of Applied Economics, 23 (1), pp. 1-18.

Stockhammer, E. (2004), "Explaining European unemployment: testing the NAIRU hypothesis and a Keynesian approach", International Review of Applied Economics, 18 (1), pp. 1-26.

\section{Appendix 1: Definitions of variables}

\begin{tabular}{llll}
\hline$n$ & employment $(\log )$ & & $r \quad$ real long-term interest rate \\
$l$ & $\quad$ labour supply $(\log )$ & & $f d \quad$ exports-imports (\% of GDP) \\
$w$ & real compensation per employee $(\log )$ & $\tau^{d}$ & direct tax rates (\% of GDP) \\
$u$ & unemployment rate $(l-n)$ & $\tau^{i}$ & indirect tax rates (\% of GDP) \\
$k$ & real capital stock $(\log )$ & $\tau^{w}$ & fiscal wedge \\
$k^{n}$ & capital stock per employee $(k-n)$ & $o$ & real oil prices (log) \\
$z$ & participation rate $\left(\frac{\text { labour force }}{\text { working-age population }}\right)$ & & \\
\hline
\end{tabular}

Source: extracted from Table 1 in Karanassou, Sala and Salvador (2008). The fiscal wedge is the sum of direct, indirect and payroll taxes as a ratio of the total compensation of the employee. 